\title{
The Effectiveness of Using Indonesian Language Learning Media Mutiara Khairani/19016179 mutiarakhairani09@gmail.com
}

Learning media is a very important thing in supporting learning, especially in Indonesian language lessons between teachers and students, both inside and outside the classroom. It is undeniable that learning media is one aspect that must exist in learning. The purpose of using the learning media itself is to facilitate the delivery of information related to Indonesian language lessons in the form of subject matter or other things that are considered important in the teaching and learning process. Of course, the trend of using learning media in the 21 st century is increasing in accordance with its development. The use of information technology is an integral part of modern education (Mulyadi, et, al., 2019)

Efforts to use information and communication technology in Indonesian language learning media are expected to improve the quality of education by developing today's modern learning. Education is a form of progress. An advanced society is characterized by the advancement of the quality education sector (Indriyani, et, Al., 2019). One way that can be done to advance education is to use learning media that are suitable for students and also of high quality.

The use of modern learning media that utilizes communication and information technology in the 21 st century introduces various creative innovations in supporting Indonesian language learning to make it more interesting and arouse students' interest in learning. Of course, if the students themselves already have a great interest then the lesson information can be accepted by students easily. According to Ramadhan et al (2019), media allows students to interact in the most modern, innovative but not too formal way in educational activities.

The use of information technology in learning in the 21 st century era can improve the quality of education in a country. As we know that we are in the era of the industrial revolution 4.0 which allows information technology to coexist with us. According to Mulyadi, et al (2019), current technology can improve the quality of learning, because technology has new concepts, such as computers, internet, multimedia, audio, video, and animation, which greatly affect the quality of education. The use of modern technology is capable and very effective in bringing about better education, effective use of time, and lower costs (Mulyadi, et al., 2019).

By using modern learning media, it is easier for students to interact with each other with teachers. The need for teachers to understand the times to encourage today's modern learning that is tailored to the needs of students so that learning can take place well. Teachers must have competence in choosing and using media in learning that is tailored to the needs of students (Ramadhan, et al., 2019). 
Various types of learning media are often used by teachers such as audio, visual, and audiovisual media. One of them uses audio-visual media that involves various senses in a learning process. Audiovisual media is media that has sound and image elements (Hartidini, et al., 2018). Media provides direct experience, can be through computers and the internet and all sources to communicate. (Novelti, et, al., 2018). The use of each type of media must be able to be used by teachers in the teaching and learning process that is adapted to various learning materials, especially in learning Indonesian. Teachers must be able to use interesting and creative learning media for students. Teachers are expected to be able to use creative media so that learning can be fun for students. According to Amalia et al (2018), this audiovisual media looks more attractive because it contains two building elements, namely images and sounds that make objects look alive and attractive.

To create an interesting, creative, efficient and innovative learning process, teachers must have competence, select teaching materials from various sources, use the latest learning tools; and using various media to create fun learning (Ramadhan, et, al., 2019). The existence of this learning media is to support Indonesian language learning taught by the teacher. Especially in the four aspects of skills that must be mastered by students. In learning there are 4 aspects of language skills that must be mastered by students, namely listening, speaking, reading, and writing skills (Andriani, et al., 2020). Students' language skills in Indonesia need to be improved, especially for writing skills (Ramadhan, et al., 2018). From these four aspects, teachers should be able to adjust how appropriate learning media are used by teachers so that learning is also fun for students.

One of the media that can be used in this 21 st century era is electronic media or digital media. This electronic media allows the delivery of information in the form of audio, visual, or audiovisual. The use of electronic media nowadays supports Indonesian language learning, especially during the current pandemic. As we know, the COVID-19 pandemic has spread widely in Indonesia. As a result of the spread of COVID-19, it affects many sectors such as the economic sector, health, and even education. Until, the government issued a policy to conduct distance learning or online to reduce the spread of covid.

For this reason, of course, this electronic media can be used as a support for online learning so that education can continue even during the pandemic. One of them is whatsapp media which is often used by teachers in the teaching and learning process. This is the importance of why teachers must be able to master information technology and follow every development of the times related to the media used in learning. According to (Ramadhan, et al., 2019) the need for professional development of teachers in digital media literacy is not an option but an obligation.

The use of interesting learning media will certainly arouse students' motivation to learn. The information received can also be captured properly. this is in accordance with the opinion of Zulhafizh, et, al. (2013) that one of the success of a person or student in mastering 
and understanding the lesson is indicated by learning outcomes. For this reason, the success of students in understanding learning, of course, is also based on interesting Indonesian language learning media used by teachers in the teaching and learning process in the classroom. If students' motivation increases in learning, the success will also be even greater.

Based on the questionnaire that the author has distributed, it is related to how Effective the Utilization of Indonesian Language Learning Media is. The author has distributed this questionnaire to equivalent high schools both in the city of Padang and outside the city of Padang. Overall respondents who filled out the questionnaire, as many as 36 high school students or equivalent. This questionnaire was distributed to students in grades $\mathrm{X}, \mathrm{XI}$, and XII. Filling out the questionnaire was dominated by class XII with 18 students or $50 \%$, Class XI with 15 students or $41.7 \%$, and Class X as many as 3 students or $8.3 \%$. Of the total respondents who filled out this questionnaire, it was more dominantly filled by women with a total of 22 people or $61.1 \%$ and men amounting to 14 people or $38.9 \%$. The results of the percentage data taken through the google form. The results of the questionnaire are as follows:

The first statement "Indonesian language teachers use interesting media in learning" $25 \%$ stated very often, $38.9 \%$ said often, $33.3 \%$, and $2.8 \%$ said never. The second statement "Teachers use electronic media in learning Indonesian" $16.7 \%$ said very often, $41.7 \%$ said often, $36.1 \%$ said sometimes, and 5.6\% said never. The third statement "Teachers use whatsapp groups to support Indonesian language learning" 50\% said very often, $38.9 \%$ said often, $8.3 \%$ said sometimes, and $2.8 \%$ said never. The fourth statement "I feel less clear in capturing the subject matter through the media used by teachers in learning Indonesian" $22.2 \%$ stated often, $72.2 \%$ stated sometimes, and 5.6\% stated never. The fifth statement "Teachers use audio, visual, and audiovisual media in supporting Indonesian language learning" $27.8 \%$ said very often, $36.1 \%$ said often, $33.3 \%$ said sometimes, and $2.8 \%$ said never. The sixth statement "I feel that the teacher has difficulty operating learning media during Indonesian lessons" 5.6\% said very often, $13.9 \%$ said often, 52.8\% said sometimes and 5.6 said never. The seventh statement "I feel learning Indonesian by using media is more interesting than just lectures" $22.2 \%$ said very often, $44.4 \%$ said often, $25 \%$ said sometimes, and $8.3 \%$ said never. The eighth statement "During the pandemic the Indonesian language learning media used by teachers helped me understand the subject matter" $25 \%$ stated very often, $44.4 \%$ said often, $25 \%$ said sometimes, and $5.6 \%$ said never. The ninth statement "Teachers use power point media in learning Indonesian, so that it makes me understand more" $16.7 \%$ said very often, $33.3 \%$ said often, $38.9 \%$ said sometimes, and $11.1 \%$ said no once. The tenth statement "Teachers continue to innovate along with the times related to media in Indonesian language learning" 33.3\% said very often, $52.8 \%$ said often, $5.6 \%$ said sometimes, and $8.3 \%$ said no once. 
Based on the data from the distribution of the questionnaires that have been carried out. The author can conclude that using learning media in Indonesian lessons is more interesting and tends to be bored if the teacher only lectures. Although sometimes the management and use of learning media by teachers still experience many obstacles, teachers continue to strive to keep up with the times and utilize media to support effective and creative learning. The use of learning media carried out by Indonesian language teachers so far can be said to be effective because teachers are able to implement these media in Indonesian language learning, especially during this pandemic which shifts face-to-face learning to online learning. Electronic learning media can be used and operated properly by teachers. The application of interesting Indonesian language learning media can make it easier for students to receive information and understand Indonesian language subject matter well. 


\section{BIBLIOGRAPHY}

Amalia, F., Syahrul, R., \& Arief, E. (2018). The Effect of Audiovisual Media Assisted Discovery Learning Model on Writing Exposition Text Skills for Eighth Grade Students of SMP Negeri 31 Padang. Journal of Indonesian Language and Literature Education , 7 (1), 125-132.

Andriani, L., Syahrul, R., \& Ermanto, YA (2020). DEVELOPMENT OF THE CIPP EVALUATION MODEL FOR COMPUTER-BASED INDONESIAN LANGUAGE LEARNING. PalArch's Journal of Archeology of Egypt/Egyptology, 17 (6), 1054010544.

Hartidini, S., Syahrul, R., \& Ratna, E. (2018). The effect of inquiry learning strategies assisted by audiovisual media on the skills of writing argumentative essays in class $\mathrm{X}$ SMA Negeri 2 Lengayang, south coast district. Journal of Indonesian Language and Literature Education , 7 (1), 63-69.

Indriyani, V., Zaim, M., Atmazaki, A., \& Ramadhan, S. (2019). Literacy and literacy and language curriculum innovation. KEMBARA: Scientific Journal of Language, Literature, and Its Teaching (e-Journal) , 5 (1), 108-118.

Mulyadi, M., Atmazaki, A., \& Syahrul, R. (2019, January). The Development of Interactive Multimedia E-Module on Indonesian Language Course. In 1st International Conference on Innovation in Education (ICoIE 2018) (pp. 291-295). Atlantis Press.

Mulyadi, M., Atmazaki, A., Agustina, A., \& Syahrul, RS (2019). THE DEVELOPMENT OF E-MODULES BASED ON ADOBE FLASH FOR INDONESIAN SUBJECTS AT IAIN BUKITTINGGI. In BiCED. Bukittinggi International Conference on Education (Vol. 1, No. 1).

Novelti, N., Ramadhan, S., Ermanto, E., \& Agustina, A. (2018). Developing an Instructional Model Assisted Audio Visual Media. Advances in Social Science, Education and Humanities Research, 263.

Ramadhan, S., Sukma, E., \& Indriyani, V. (2019). Teacher competence in utilizing digital media literacy in education. In Journal of Physics: Conference Series (Vol. 1339, No. 1, p. 012111). IOP Publishing.

Ramadhan, S., Asri, Y., \& Indriyani, V. (2018). Learning module design writing argumentative text based problem-based learning. Advances in Social Science, Education and Humanities Research, volume 263.

Zulhafizh, A., \& Syahrul, R. (2013). Contribution of students' attitudes and learning motivation to Indonesian language learning outcomes. Journal of Language, Literature and Learning , 1 (2), 13-28. 